Pakistan Journal of Social Sciences 16 (3-6): 55-59, 2019

ISSN: 1683-8831

(C) Medwell Journals, 2019

\title{
Impact of Low Cost Teaching Material on Studentscreativity in Chemistry at Secondary Level
}

\author{
Umar Khitab \\ Department of Chemistry, Education Department KPK, Peshawar, Pakistan
}

\begin{abstract}
This study aimed to find out the impact of low cost teaching material on student' s reativity in chemistry at secondary level. A sample of 60 students was none-randomly selected from class ten on the basis of pre-test and demographic detail from Government Higher School Mian Brangola Dir (Lower) for this study. This was an experimental study. Therefore, two groups, i.e., control and experimental (treatment) group were designed. Each group contained 30 students. A creativity test, developed by Khitab was used as a research tool for the collection of data. The test is comprised of five components, i.e., sensitivity to the problem, fluency, flexibility, originality and elaboration and redefinition and has a reliability coefficient 0.91 . The treatment group was lectured $t$ with low cost activities whereas the control group was taught the same topics through traditional method by the researcher himself for 15 days regularly. The topics were selected with the help of the concerned science teachers the 10th class chemistry text book. For analyzing the collected data t-test was used. The result showed that teaching with low cost material is more effective for developing of creative thinking of the students.
\end{abstract}

$\underline{\text { Key words: } \text { Creativity, creativity test, activity based teaching, lost cost teaching material, lectured, cost }}$

\section{INTRODUCTION}

To develop creativity of the young student's science involves to provide opportunities in the form of generating new ideas, solve the problems and to investigate how to manipulate the material. Young students are instinctive explorers; they need a right environment to be creative. By right environment, it means creative teaching and creative learning process. In the creative learning process the students focus on discussion, teamwork and emphasize on deep conceptual understanding not for mere mastery. Science is an activity based approach. It is being taught with activities which develop the conceptual understanding, the critical and creative thinking of the students. Young students cooperate with each other during construction activities, keep themselves involve in sharing ideas and doing something in a new way. Therefore, Activity Based Teaching (ABT) plays a leading role in creating student's creativity. This approach is in contrast to some other tradition, teaching approaches in which the students absorb the communicating information what they are told. In $A B T$ approach the educators practically serve the function of facilitation and have the responsibility of providing the students with guidance to make them active participant in teaching learning process. For such type of activities the existence of laboratories is foremost but unfortunately, there are no laboratories available for young students in the schools, especially in Khyber Pakhtunkhwa and those having laboratories are not well equipped. However, this deficiency may be overcome in the form of designing and fabricating low cost teaching materials in laboratories. We can use low cost material found around us as used up and thrown away here and there in laboratories for effective learning to develop the creative thinking of our students.

In short, creativity is an imperative aspect in the creation teaching learning process for the students, especially with reference to the teaching of chemistry. In advance countries modern technologies are used to develop the creative thinking of the students in chemistry but in the third world countries like Pakistan, it is difficult to facilitate our students with modern technology. Consequently, we can utilize low cost materials for teaching purposes in laboratories to keep the students on the scientific track to flourish their creativity. Therefore, the investigator made an effort to find out the impact of low cost teaching material on student creativity in chemistry at secondary.

Literature review: There are mixed findings of different researches about the use of low cost material for teaching science. Singh and Kaur (2012) conducted his study on elementary teachers in 50 government schools to find out whether they used low cost/no cost to teaching material in laboratories for teaching of science. The investigators reached at the conclusion that the use of low cost/no cost teaching material was below average at this level in the teaching of science. The elementary teachers did not use low cost/no cost teaching material every topic. According to the elementary teachers the fabrication of low cost teaching material and plan a lesson demand extra time. 
Similarly, Ali and Papaiah (2015) reached at the conclusion that there was no learning by doing and innovative utilization and operation of low cost equipment by secondary school science teachers in laboratories in teaching of science subjects . The investigators found a pitiable scenario because $50 \%$ of elementary teachers could not utilize and fabricate low cost/no cost material. However, some teachers were interested and bought some ready made low cost/no cost teaching material personally.

Low cost/no cost teaching materials provide hands on activities that are important for the active learning because due to limited resources most schools do not have well equipped high cost/expenditure science laboratories, especially, chemistry laboratory. Khitab (2004) concluded in his study that most of high and higher secondary schools did have well equipped laboratories to engage the students in active and creative learning process. Consequently, elementary chemistry teachers may fabricate and design, low cost/no cost equipment from easily available materials around us. According to Shafiq (Personal communication, March 2010) science teachers can use low cost/no cost materials for the fabrication of equipment that can be used in laboratories for effective learning to increase the student's creativity and achievement.

Low cost teaching materials increase the capacity and tendency of the students to scrutinize and observe. As Yitbarek (2012) believes that low cost teaching materials increase the competence of the students to observe, make clear and do actual science. And in financial difficulties and constrictions low cost /no cost teaching materials are the alternative solutions of high cost equipment to perform activities in science laboratories. Similarly, Ara (1998) favors the effectiveness of the use of low cost instruction equipment for the chemistry teaching at secondary level for the development of scientific skills of the students. Mishra and Yadav (2013), stress on the use of low cost teaching materials which can shift the costlyscientific kit to low cost/no cost tools and equipment. Tesfaye et al. (2011) reached at the conclusion that the adequate equipment and the shortage of the laboratories is the serious future concern. Therefore, the utilization of low cost apparatus fabricated from locally available resources instead of high cost apparatus is needed.

Usman (2000) is of the opinion that students show poor performance in science concepts because there are no teaching facilities and the students are enforced to rote learning rather than to be involved in activities. However, Adeniyi and Anetor (1999) and David have the same opinion that though science teaching capability amd copetence are essential but the teachers find difficult to manage the activity based instruction due to lack of their preparation. Sivakumar conducted an experimental study to locate the effectiveness of teaching through, activities performed with low cost equipment in teaching science subjects. About 80 students were taken as a sample. Treatment group was taught with low cost teaching aids. It was winded up that the treatment group performed better than the traditional group students. Therefore, teaching with low cost teaching kit is more successful and effectual than, teaching with other traditional methods.

Objectives of the study: This particular study has single objective: to find out the impact of low cost teaching materials on student's creativity in chemistry at the secondary level.

\section{MATERIALS AND METHODS}

Hypothesis: Single null hypothesis was formulated to be tested:

- $\mathrm{H}_{01}$ : there was no impact of low cost teaching on student's creativity in Chemistry at secondary level

Population of the study: All the grade ten science male students of the public and private high/higher secondary schools of Khyber Pakhtunkhwa constituted the population.

Sample/sampling technique of the study: All the 10th grade science male students enrolled in Government Higher Secondary School Mian Brangola Die (Lower), Khyber Pakhtunkhwa. The convenient sampling technique was taken on owing to the scenery of the study A sample of 60 out of 117 students was none-randomly selected from class ten on the basis of pre-test and demographic detail. Two groups, i.e., experimental (treatment) and control (traditional) were formed.

\section{Content of the study:}

- Low cost acetylene gas apparatus for the preparation of acetylene gas and to show it physical and chemical properties

- Low cost apparatus of the Nelson cell for the preparation of sodium hydroxide, chlorine, hydrogen gas and their properties

- Low cost electrolysis apparatus

- Some vegetables for the preparation of indicators

- Periodic chart

Research design: Experimental design was adopted for this study which involved two groups, experimental and control. The groups were non-randomly formed on the basis of collecting demographic details of the 10th grade science students from the sample school records and pre-test for grouping. Owing to experimental design all the internal and external threats were controlled.

Instrument: For the collection of data a well developed creativity test by Khitab (2011) was used as a tool. This 
test was consist of five components, i.e., sensitivity to the problem, fluency, flexibility, originality and elaboration and redefinition. The creativity test has a reliability coefficient 0.91 .

Procedure: The treatment group was skilled through activities with low cost material whereas the control group was taught the same topics through traditional method by the researcher himself for 15 days regularly. The topics were selected with the help of the concerned science teachers the 10th class chemistry text book. Creativity test was administered to both experimental and control groups to collect the data for testing the hypothesis after treatment.

\section{RESULTS AND DISCUSSION}

Analysis and interpretation of the data: Independent sample t-test using SPSS-17 version was applied to find out the significant difference of the two groups on the bases of mean scores at the significance level of 0.05 .
Moreover, the Cohen's d effect size using formula was also applied for calculating, weighing and appraising the quantityand amount of each pair of the mean scores. All the obtained statistical data from creativity components and their resultare given in the following Table 1.

Table,1, shows that all the mean scores of the variables of creativity test of the experimental groups are higher than the control groups which indicates that there is a significant difference between the two groups at 0.05 levels. Consequently, it can be concluded that experimental group accomplished themselves and performed very well their creativity test. The students of the experimental group were more astonished and flabbergasted by teaching with low cost apparatus.

Additionally, the Cohen's d effect size values 0.97, $0.90,0.94,0.97,0.96>0.8$. This indicated that all factors of the creativity proved large effect size. Therefore, the null hypothesis, $\mathrm{H}_{\mathrm{o} 1}$ which claimed "there is no impact of teaching low cost materials on student's creativity in chemistry at secondary level" of the study is therefore, rejected (Fig. 1).

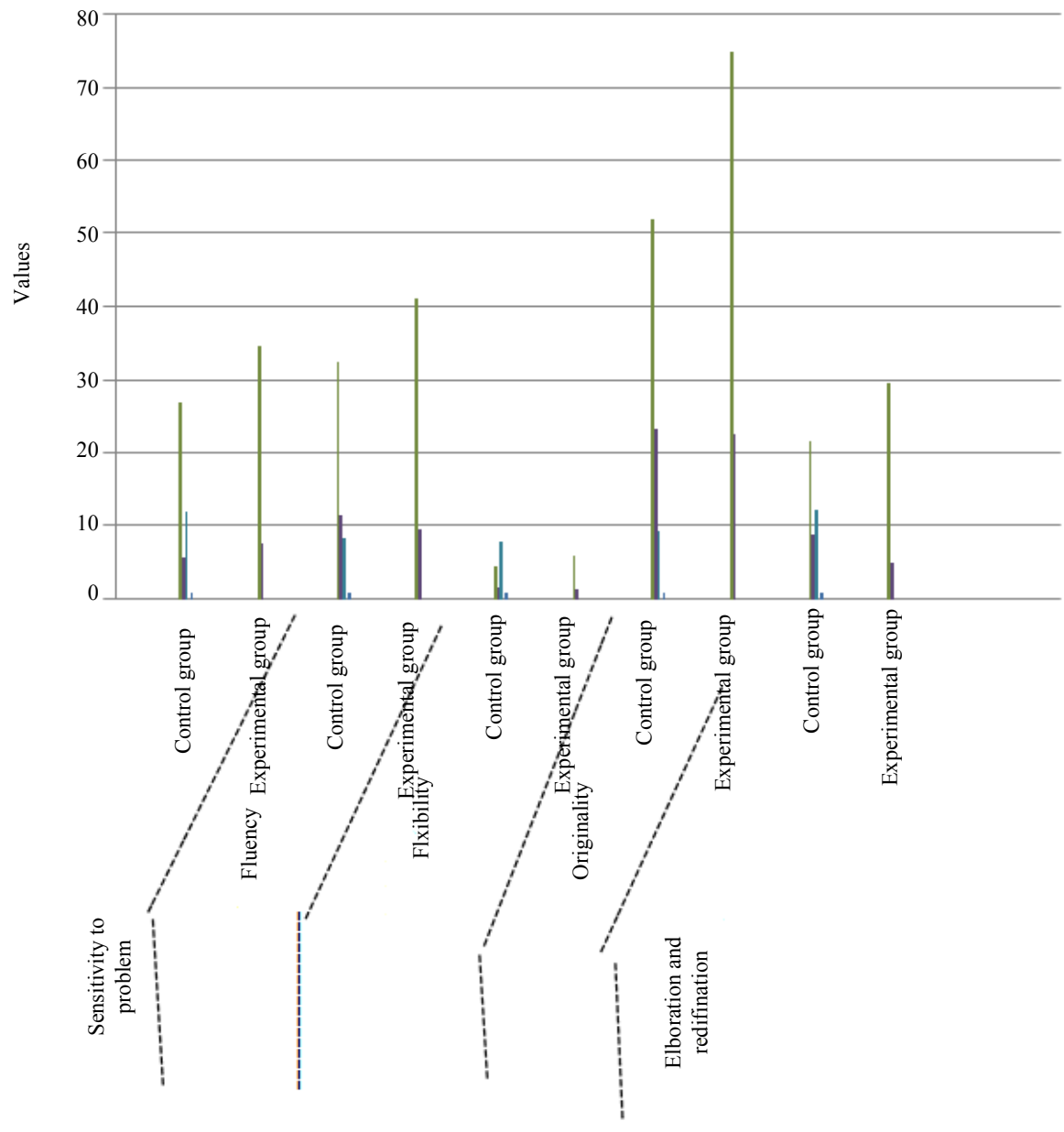

Fig. 1: Summarizes the results or experimental and control groups for the creativity test (Comparison of mean score) 
Pak. J. Soc. Sci., 16 (3-6): 55-59, 2019

Table 1: Comparison of the scores of experimental and control groups of the creativity test

\begin{tabular}{|c|c|c|c|c|c|c|c|}
\hline Variables & Groups & $\mathrm{N}$ & Mean & $\mathrm{t}$-values & $\mathrm{SD}$ & Cohen's d & Sig. \\
\hline \multirow[t]{2}{*}{ Sensitivity to the problem } & Experimental control & 30 & 35.12 & 13.10 & 12.14 & 0.977 & 0.000 \\
\hline & & 30 & 28.10 & & 7.64 & & \\
\hline \multirow[t]{2}{*}{ Fluency } & Experimental control & 30 & 41.33 & 17.95 & 9.64 & 0.900 & 0.000 \\
\hline & & 30 & 31.57 & & 11.67 & & \\
\hline \multirow[t]{2}{*}{ Flexibility } & Experimental control & 30 & 7.01 & 7.863 & 1.39 & 0.940 & 0.000 \\
\hline & & 30 & 4.59 & & 1.66 & & \\
\hline \multirow[t]{2}{*}{ Originality } & Experimental control & 30 & 73.99 & 9.587 & 22.67 & 0.970 & 0.000 \\
\hline & & 30 & 50.78 & & 23.47 & & \\
\hline \multirow[t]{2}{*}{ Elaboration and redefinition } & Experimental control & 30 & 30.12 & 12.71 & 5.11 & 0.960 & 0.000 \\
\hline & & 30 & 22.46 & & & 0.900 & \\
\hline
\end{tabular}

Significance level $\mathrm{p}<0.05, \mathrm{df}=29$, Standard Cohen’s d effect value $=0.8$ (which represents large effect size comparing two means)

Table 2: Comparison of the of experimental and control groups of the creativity test

\begin{tabular}{|c|c|c|c|c|c|c|c|}
\hline Groups & $\mathrm{N}$ & Mean & t-values & $\mathrm{df}$ & SD & Cohen's d & Sig. \\
\hline Experimental & 30 & 184.90 & 14.30 & 58 & 37.80 & 0.936 & 0.00 \\
\hline Control & 30 & 145.77 & 48.05 & & & & \\
\hline
\end{tabular}

Significance level $\mathrm{p}<0.05$

Table 2, shows that all the mean score creativity test of the experimental groups is higher than the controlgroups which specifies that there is a significant difference between the two groups at 0.05 levels. The lesser Standard Deviation (SD $=37.803$ ) of experimental group justifies that students of this group were concentrated and contemplated on activities performed with low cost material. In addition, the Cohen's d value $0.926>0.8$ favors the larger size in the case of the experimental group.

\section{CONCLUSION}

From the above result, it was concluded that there was a constructive, productive and dynamic impact of low cost teaching material on student's creativity in chemistry at the secondary level. Although, before the treatment both groups, i.e., experimental and control were equal scholastic performed. As the experimental group was taught with low cost activity, therefore, this group dominated the control group in all aspects of creativity. This domination of the students shows that they do not believe blindly in science teaching that leads to the basic philosophy of teaching science with the activity based approach. The results of this study justified the importance of teaching with low cost materials for higher order thinking of the students to produce new ideas, experimental imagination and identification of difficulties and solution of problems, therefore, equipments of low cost materials must be inculcated in the curriculum of secondary school. These results are supported by the finding of many past researchers like, however, this finding warrants further investigation in future research with low cost teaching material.

\section{RECCOMENDATIONS}

Imperative and central recommendations are represented on the support of the findings and conclusion of this study. Particular focus may be given to include hands on activities with low cost materials in the curriculum for higher secondary level to ensure higher creativity of the students at this level.

Various trainings for the teachers may be arranged to fabricate various types of low cost activities. Awareness may be prevailed among teachers by arranging in-service training programs, conferences, seminars, workshops on regular bases.

\section{REFERENCES}

Adeniyi, F.A. and J.I. Anetor, 1999. Lead-poisoning in two distant states of Nigeria: an indication of the real size of the problem. Afr. J. Med. Sci., 28: 107-112.

Ali, S.L. and M. Papaiah, 2015. Theme: Learning by doing sub theme: Innovative use of low cost/no cost teaching learning materials. Int. J. Humanities Social Sci. Invention, ISSN (Online), 4: 2319-7722.

Ara, I.H., 1998. Activities based on low-cost materials (equipment, glassware, chemicals) in teaching chemistry at secondary school level in Pakistan. Ph.D. Thesis, University of Peshawar, Peshawar, Pakistan.

Khitab, U., 2004. A study on the causes of poor achievement of science students in the subject of chemistry at secondary level in district Dir (lower). M.Ed. Thesis, Allama Iqbal Open University, Islamabad, Pakistan.

Khitab, U., 2011. The development of low cost learning material for the teaching if chemistry at secondary Level. M. Phil Thesis, University of Science and Technology, Peshawar, Pakistan.

Mishra, S.K. and B. Yadav, 2013. Effect of activity based approach on achievement in science of students at elementary stage. Int. J. Basic Appl. Sci., 1: 716-733. 
Singh, M. and D. Kaur, 2012. Use of low cost-no cost teaching material by elementary school teachers in teaching of science. Scolarly Res. J. Interdiscip. Stud., 1: 90-99.

Tesfaye, T., S. Yitbarek and A. Tesfaye, 2011. The status of science education in Addis Ababa Primary Schools. Ph.D. Thesis, City Government of Addis Ababa Education Bureau, Addis Ababa, Ethiopia.
Usman, I.A., 2000. The relationship between student's performance in practical activities and their academic achievement in integrated science using NISTEP mode of teaching. Ph.D. Thesis, Ahmadu Bello University, Zaria, Nigeria.

Yitbarek, S., 2012. Low-cost apparatus from locally available materials for teaching-learning science. Afr. J. Chem. Educ., 2: 32-47. 